\title{
IMPLEMENTASI MODIKAR PEKASI PADA MATA KULIAH PRAKTIK DI FAKULTAS TEKNIK UNIVERSITAS NEGERI YOGYAKARTA
}

\author{
Rafi Nurul A'la ${ }^{1}$ dan Amat Jaedun² \\ ${ }^{1,2}$ Pendidikan Teknik Sipil dan Perencanaan, FT, UNY \\ Email: jaedun@uny.ac.id
}

\begin{abstract}
ABSTRAK
Penelitian ini dilakukan untuk (1) mengetahui pemahaman dosen Fakultas Teknik Universitas Negeri Yogyakarta (FT UNY) yang mengampu mata kuliah praktik kerja terhadap model pendidikan karakter untuk pembelajaran vokasi (Modikar Pekasi), (2) mengetahui tingkat kepraktisan Modikar Pekasi, dan (3) mengetahui tingkat keefektifan Modikar Pekasi. Jenis penelitian ini adalah deskriptif kuantitatif yang dilakukan melalui metode survei. Populasi penelitian ini adalah dosen FT UNY yang mengampu mata kuliah praktik kerja. Sampel pada penelitian ini sebanyak 8 dosen dengan masing-masing blok jurusan sebanyak 2 dosen ditentukan melalui teknik kuota sampling. Pengumpulan data dilakukan dengan menggunakan angket. Analisis data menggunakan analisis statistik deskriptif. Hasil penelitian menunjukkan bahwa: (1) tingkat pemahaman dosen FT UNY terhadap Modikar Pekasi berada pada kategori sangat paham dengan nilai rerata sebesar 3,33 dalam skala $1-4$, (2) tingkat kepraktisan Modikar Pekasi menurut penilaian dosen adalah mudah dilaksanakan dengan nilai rerata sebesar 3,00 dalam skala $1-4$, dan tingkat efektivitas Modikar Pekasi menurut penilaian dosen termasuk kategori efektif dengan nilai rerata sebesar 2,89 dalam skala $1-4$.
\end{abstract}

Kata kunci: Pendidikan karakter, Praktik kerja, dan Modikar pekasi

\section{ABSTRACT}

This research was conducted to (1) determine the understanding of the lecturers of the faculty of engineering, Universitas Negeri Yogyakarta (UNY) who is in charge of practical work courses on character education models for vocational learning (modikar pekasi), (2) determine the practicality level of modikar pekasi, and (3) know the level of effectiveness of modikar pekasi. This type of research is descriptive quantitative conducted through survey methods. The population of this research is FT UNY lecturers who teach practical work courses. The sample in this study were 8 lecturers with 2 lecturers in each department block determined through quota sampling technique. Data collection was done by using a questionnaire. Data analysis used descriptive statistical analysis. The results pointed out: (1) the level of understanding of the FT UNY lecturers towards modikar pekasi was in the category of very understanding with an average value of 3.33 on a scale of $1-4,(2)$ the practicality level of modikar pekasi according to the lecturer's assessment was easy to implement with an average value of 3.00 on a scale of 1 - 4, and (3) the level of effectiveness of modikar pekasi according to the lecturer's assessment was in the effective category with an average value of 2.89 on a scale of $1-4$.

Keywords: Character Education, Work Practices, and Modikar Pekasi

\section{PENDAHULUAN}

Undang-undang Nomor 12 tahun 2012, tentang pendidikan tinggi, pasal 4, menyatakan bahwa pendidikan tinggi berfungsi mengembangkan kemampuan dan membentuk watak serta peradaban bangsa yang bermartabat dalam rangka mencerdaskan kehidupan bangsa. Selanjutnya, pasal 5 menyatakan bahwa pendidikan

tinggi

bertujuan mengembangkan potensi mahasiswa agar menjadi manusia yang beriman dan bertakwa kepada Tuhan Yang Maha Esa dan berakhlak mulia, sehat, berilmu, cakap, kreatif, mandiri, terampil, kompeten, dan berbudaya untuk kepentingan bangsa. Demikian pula, Peraturan Pemerintah nomor 17 tahun 2010, pasal 84, ayat (2), menyebutkan bahwa perguruan tinggi 
memiliki tujuan membentuk insan yang beriman dan bertaqwa kepada Tuhan Yang Maha Esa, berakhlak mulia, dan berkepribadian luhur, sehat, berilmu dan cakap, kritis, kreatif, inovatif, mandiri, percaya diri, dan berjiwa wirausaha, serta toleran, peka sosial dan lingkungan, demokratis dan bertanggung jawab. Untuk menghasilkan lulusan perguruan tinggi sebagaimana disebutkan di atas, maka sudah seharusnya bahwa pembelajaran di perguruan tinggi tidak hanya membekali para lulusan dalam hal pengetahuan dan keterampilan saja, tetapi juga mengembangkan potensi yang ada dalam diri mahasiswa yang bersangkutan, termasuk karakter dan akhlak mulia.

Namun demikian, Hasanah (2013) menyatakan bahwa sistem pendidikan di Indonesia secara umum masih menitikberatkan pada pengembangan kecerdasan kognitif. Hal ini dapat dilihat dari orientasi lembaga pendidikan kita yang masih disibukkan dengan ujian, mulai dari ujian tengah semester, ujian akhir semester hingga ujian nasional. Mulyadin dan Amat Jaedun (2019) juga menyatakan bahwa dalam kenyataannya pendidikan kita saat ini masih kurang menekankan pada pendidikan karakter/moral siswa, akan tetapi lebih menekankan pada peningkatan intelektualitas, kurang membangun kepribadian dan moral siswa, sehingga masih banyak siswa yang melakukan kegiatan yang menyimpang. Sementara itu, Kurniasih dkk. (2017) menyatakan bahwa implementasi kebijakan pendidikan karakter dalam sistem pendidikan di Indonesia masih menghadapi tantangan utama yaitu untuk meningkatkan hasil pembelajaran yang masih rendah. Hal ini berarti bahwa kebijakan pendidikan karakter dan kebijakan peningkatan mutu hasil belajar seakan-akan merupakan dua kebijakan yang saling bertolak belakang. Sehingga kebijakan pendidikan karakter merupakan pilihan yang sulit, karena kita tidak boleh mengabaikan upaya peningkatan mutu pendidikan kita yang juga masih rendah.

Universitas Negeri Yogyakarta sebagai perguruan tinggi yang memiliki motto Leading In Character Education telah berusaha melakukan integrasi pendidikan karakter dalam berbagai aktivitas dan program termasuk dalam proses pembelajaran. Zuchdi (2012:10) memaparkan bahwa pendidikan karakter di UNY dilakukan melalui program pelatihan dan pendidikan dengan mengintegrasikan pengembangan kreativitas, workshop Emotional and Spritual Quotient bagi masyarakat kampus mulai pimpinan, dosen, hingga mahasiswa, dan pelatihan soft skill. Sejalan dengan hal itu, proses pendidikan karakter juga terintegrasi dalam pembelajaran mata kuliah praktik kerja di FT UNY. Setidaknya nilai-nilai karakter kerjasama, saling membantu antar mahasiswa, dan kerja keras ditanamkan melalui proyek tugas kelompok maupun individu di bengkel/workshop/tempat belajar keterampilan. Selain itu, tugas projek juga diberikan untuk menumbuhkan kreativitas, kerjasama, dan kepekaan peserta didik untuk dapat saling membantu.

Namun demikian, proses implementasi pendidikan karakter dalam lembaga pendidikan sangat rentan menghadapi berbagai macam kendala yang diakibatkan oleh program yang dibuat tidak tepat bagi peserta didik, pendidik yang kurang kompeten, tidak ada teladan yang baik dari pendidik, tidak ada komunikasi dan kurangnya dukungan dari orangtua siswa, dan satuan pendidikan atau pendidik tidak mampu mengevaluasi programnya secara 
baik (Suparno, 2012). Oleh karena itu, langkah lain yang dapat dilakukan dalam upaya pengintegrasian pendidikan karakter dalam proses pembelajaran adalah merumuskan rancangan Model Pendidikan Karakter Untuk Pembelajaran Vokasi (Modikar Pekasi). Model ini merupakan hasil pengembangan model pendidikan karakter yang dihasilkan dari penelitian Sutarto dkk. (2019) sebagai kerja sama antara Fakultas Teknik Universitas Negeri Yogyakarta Indonesia dan Fakulti Pendidikan Teknikal dan Vokasional Universiti Tun Hussein onn Malaysia pada tahun 2019. Modikar Pekasi menerapkan berbagai strategi yang relevan dengan proses pembelajaran mata kuliah praktik kerja di FT UNY. Berbeda dengan model yang telah diterapkan sebelumnya, konsep peningkatan mutu berkelanjutan pada Modikar Pekasi menjadi nilai penting yang dapat meningkatkan kualitas relevansi model pendidikan karakter dengan proses pembelajaran mata kuliah praktik kerja di FT UNY.

Berdasarkan pada latar belakang tersebut, maka penelitian ini bertujuan untuk: (1) mengetahui pemahaman dosen mata kuliah praktik kerja terhadap Modikar Pekasi; (2) mengetahui penilaian dosen terhadap tingkat kepraktisan Modikar Pekasi; dan (3) mengetahui penilaian dosen terhadap tingkat keefektifan Modikar Pekasi.

Lickona (1992:12) menyatakan bahwa pendidikan karakter merupakan upaya untuk membantu peserta didik dalam memahami, peduli dan bertindak sesuai dengan nilainilai yang berlaku dalam suatu masyarakat. Pendidikan karakter menurut Lickona memiliki tiga unsur pokok yaitu "membantu seseorang dalam mengetahui kebaikan (knowing the good), membantu seseorang dalam mencintai kebaikan (desiring the good), dan membantu seseorang untuk melakukan kebaikan (doing the good)."

Rosalin (2016:24) menyebutkan bahwa secara operasional tujuan pendidikan karakter dalam perspektif lembaga pendidikan yaitu (1) berupaya menguatkan dan mengembangkan berbagai nilai kehidupan yang dianggap penting dan perlu sehingga peserta didik mempunyai pribadi yang khas sesuai dengan nilai-nilai yang dikembangkan. (2) berupaya mengoreksi peserta didik apabila memiliki nilai karakter yang tidak sesuai dengan apa yang dikembangkan oleh sekolah. (3) berupaya membangun koneksi yang baik dengan keluarga dan masyarakat sebagai pihak yang memiliki tanggungjawab dalam melaksanakan pendidikan karakter kepada peserta didik.

Kementerian Pendidikan Nasional (2010: 3) menyampaikan 11 prinsip dalam mewujudkan pendidikan karakter yang efektif disarikan dari CEP's Eleven Principles of Effective Character Education By Thomas Lickona adalah (1) mempromosikan nilai dasar etika selaku basis dan inti karakter; (2) mengidentifikasi karakter secara menyeluruh mencakup perasaan, perilaku dan pemikiran; (3) menggunakan metode yang proaktif, mendalam dan efektif dalam membangun karakter; (4) menciptakan komunitas sekolah yang memiliki rasa peduli; (5) memberikan kesempatan kepada peserta didik untuk mengimplementasikan perilaku yang baik; (6) memiliki cakupan pada kurikulum yang bermakna dan menantang yang menghargai semua peserta didik, membangun karakter mereka, dan membantu mereka untuk sukses; (7) mengusahakan tumbuhnya motivasi diri pada pada peserta didik; (8) memfungsikan 
seluruh staf sekolah sebagai komunitas moral yang berbagi tanggungjawab untuk pendidikan karakter dan setia pada nilai dasar yang sama; (9) adanya pembagian kepemimpinan moral dan dukungan luas dalam membangun inisiatif pendidikan karakter; (10) memfungsikan keluarga dan anggota masyarakat sebagai mitra dalam usaha membangun karakter; mengevaluasi karakter sekolah, fungsi staf sekolah sebagai guru-guru karakter, dan manifestasi karakter positif dalam kehidupan peserta didik.

Sejalan dengan hal tersebut, Zuchdi (2010:35) menyampaikan bahwa pendidikan karakter yang bertumpu terhadap satu strategi saja sudah tidak relevan untuk dapat mengembangkan nilai-nilai perilaku yang baik kepada peserta didik. Oleh karena itu dalam mengembangkan model pendidikan karakter diperlukan beberapa pendekatan yang salah satunya adalah pendekatan komprehensif. Pendekatan ini mencakup aspek isi, metode, proses, subyek, dan evaluasi. Dengan menggabungkan tiga konsep pembelajaran, konsep pembelajaran Joice dan Weill, konsep kesatuan tiga ranah capaian belajar Bloom dan Krathwol dan konsep peningkatan mutu berkelanjutan CQI (Continous Quality Improvement) melalui tahapan PDCA (Plan, Do, Check, Action). Dengan langkah tersebut, Modikar Pekasi diharapkan mampu menjadi model pendidikan karakter yang relevan untuk digunakan pada pembelajaran vokasi.

\section{METODE}

Penelitian merupakan penelitian deskriptif kuantitatif yang dilakukan melalui metode survei. Penelitian ini dilaksanakan di Fakultas Teknik, Universitas Negeri Yogyakarta. Populasi penelitian ini adalah dosen pengajar mata kuliah praktik kerja, yang berasal dari empat blok jurusan, yaitu: blok Jurusan Pendidikan Teknik Boga dan Busana, blok Jurusan Pendidikan Teknik Sipil dan Perencanaan, blok Jurusan Pendidikan Teknik Mesin dan Otomotif, serta blok Jurusan Pendidikan Teknik Elektro, Elektronika dan Informatika. Sampel penelitian ini berjumlah delapan orang dosen yang ditentukan dengan teknik kuota sampling dengan proporsi dua orang dosen dari masing-masing blok jurusan. Penelitian ini difokuskan pada proses pembelajaran yang dilakukan oleh dosen mata kuliah praktik kerja pada situasi dan kondisi sebelum pandemi covid-19 terjadi. Penelitian ini dilakukan pada rentang waktu bulan November 2020 - Januari 2021

Pengumpulan data pada penelitian ini dilakukan dengan menggunakan teknik kuesioner atau angket. Kuesioner ini diberikan kepada dosen untuk menggali data tentang pemahaman dosen terhadap Modikar Pekasi, penilaian dosen tentang kepraktisan Modikar Pekasi dan penilaian dosen tentang efektivitas dari Modikar Pekasi. Instrumen penelitian yang berupa kuesioner bentuk tertutup menggunakan skala Likert, dengan empat pilihan jawaban sesuai rumusan pertanyaan yang diajukan.

Analisis data dalam penelitian ini menggunakan teknik analisis data statistik deskriptif, dengan menghitung nilai rata-rata (mean), nilai tertinggi, nilai terendah, dan standar deviasi (SD). Nilai mean selanjutnya diinterpretasikan berdasarkan kriteria dalam bentuk kurve normal, yang didasarkan pada nilai rerata ideal (Mi), dan standar deviasi ideal (SDi), sebagai berikut:

$$
\begin{aligned}
& \mathrm{Mi}=1 / 2(\text { Skor Tertinggi }+ \text { Skor Terendah) } \\
& \mathrm{SDi}=1 / 6 \text { (Skor Tertinggi }- \text { Skor Terendah) }
\end{aligned}
$$


Implementasi Modikar... (Rafi Nurul/ hal. 11-22)

Berdasarkan skor ideal tersebut, maka selanjutnya interpretasi tingkat implementasi pendidikan karakter Modikar Pekasi didasarkan pada tabel penentuan kategori sebagai berikut.

Tabel 1. Penentuan Kategori Tingkat Implementasi

\begin{tabular}{cc}
\hline Interval & Kategori \\
\hline $\mathrm{X} \geq \mathrm{Mi}+1,5 \mathrm{SDi}$ & Sangat Baik \\
$\mathrm{Mi} \leq \mathrm{X}<\mathrm{Mi}+1,5 \mathrm{SDi}$ & Baik \\
$\mathrm{Mi}-1,5 \mathrm{SDi} \leq \mathrm{X}<\mathrm{Mi}$ & Kurang Baik \\
$\mathrm{X}<\mathrm{Mi}-1,5 \mathrm{SDi}$ & Sangat Kurang Baik \\
\hline
\end{tabular}

\section{HASIL DAN PEMBAHASAN}

Deskripsi hasil penelitian mengacu pada tujuan penelitian sebagai berikut: (1) pemahaman dosen terhadap Model Pendidikan Karakter Pembelajaran Vokasi (Modikar Pekasi), (2) penilaian dosen mengenai kepraktisan Modikar Pekasi untuk diintegrasikan dalam proses pembelajaran mata kuliah praktik kerja, dan (3) penilaian dosen mengenai efektivitas Modikar Pekasi untuk diintegrasikan dalam proses pembelajaran mata kuliah praktik kerja.

1. Pemahaman Dosen Terhadap Modikar Pekasi

Data tingkat pemahaman dosen terhadap Modikar Pekasi dikumpulkan dengan menggunakan instrumen angket bentuk tertutup. Angket yang digunakan terdiri atas 25 pertanyaan mencakup pertanyaan pemahaman pada tahap Plan $(\mathrm{P})$ atau perencanaan pembelajaran, Do (D) atau pelaksanaan pembelajaran, tahap Check (C) atau evaluasi pembelajaran, dan tahap Act (A) atau tindak lanjut hasil pembelajaran sesuai model yang dikembangkan.

Data tingkat pemahaman dosen terhadap Modikar Pekasi menunjukkan bahwa dari sebanyak delapan dosen yang menjadi responden penelitian diperoleh nilai rata-rata sebesar 3,22 (skala 1 -4); nilai rata- rata minimum sebesar 2,88 dan rata-rata maksimum sebesar 3,88; dengan standar deviasi sebesar 0,60. Selanjutnya, distribusi data tingkat pemahaman dosen terhadap Modikar Pekasi terkait kategori pemahaman disajikan pada Tabel 2 berikut.

Tabel 2. Distribusi Tingkat Pemahaman Dosen terhadap Modikar Pekasi

\begin{tabular}{|c|c|c|c|c|}
\hline \multirow[b]{2}{*}{ No } & \multirow[b]{2}{*}{ Kategori } & \multirow[b]{2}{*}{ Interval } & \multicolumn{2}{|c|}{ Frekuensi } \\
\hline & & & Frekuensi & $\begin{array}{c}\text { Persen } \\
(\%)\end{array}$ \\
\hline 1 & $\begin{array}{l}\text { Sangat } \\
\text { Paham }\end{array}$ & $\begin{array}{l}X> \\
3,25\end{array}$ & 4 & 50,00 \\
\hline 2 & Paham & $\begin{array}{c}2,5 \leq X \\
<3,25\end{array}$ & 4 & 50,00 \\
\hline 3 & $\begin{array}{l}\text { Kurang } \\
\text { Paham }\end{array}$ & $\begin{array}{c}1,75 \leq \\
X<2,5\end{array}$ & 0 & 0,00 \\
\hline 4 & $\begin{array}{c}\text { Sangat } \\
\text { Tidak } \\
\text { Paham } \\
\end{array}$ & $\begin{array}{l}X< \\
1,75\end{array}$ & 0 & 0,00 \\
\hline & Jumlah & & 8 & 100,00 \\
\hline
\end{tabular}

Data pada Tabel 3 menunjukkan bahwa distribusi frekuensi pemahaman dosen terhadap Modikar Pekasi berada pada interval $\mathrm{X}>$ 3,25 dengan kategori sangat paham, dengan persentase sebesar 50,00\%; dan berada pada interval 2,5 $\leq X<3,25$ dengan kategori paham, dengan persentase sebesar 50,00\%. Sementara itu, tidak ada dosen yang kurang paham dan sangat tidak paham terhadap Modikar Pekasi. Selanjutnya, data tersebut disajikan dalam bentuk diagram batang sebagai berikut. 
Implementasi Modikar... (Rafi Nurul/ hal. 11-22)

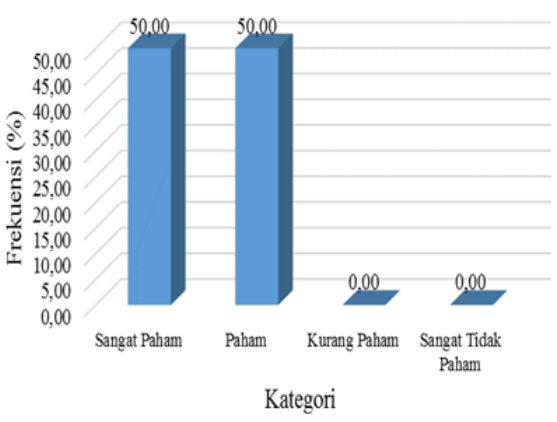

Gambar 1. Distribusi Tingkat Pemahaman Dosen terhadap Modikar Pekasi

\section{Kepraktisan Modikar Pekasi}

Penilaian dosen mengenai tingkat kepraktisan Modikar Pekasi untuk diintegrasikan ke dalam pembelajaran mata kuliah praktik kerja, dikumpulkan dengan instrumen angket tertutup.

Data penilaian dosen mengenai kepraktisan Modikar Pekasi untuk diintegrasikan ke dalam pembelajaran mata kuliah praktik kerja, menunjukkan bahwa dari sebanyak delapan dosen yang menjadi responden penelitian diperoleh nilai rata-rata sebesar 3,00 (skala 1 - 4); nilai rata-rata minimum sebesar 2,78 dan rata-rata maksimum sebesar 3,22; dengan standar deviasi sebesar 0,47. Selanjutnya, data penilaian dosen mengenai kepraktisan Modikar Pekasi untuk diintegrasikan ke dalam pembelajaran mata kuliah praktik kerja terkait kategori tingkat kepraktisan diilustrasikan pada Tabel 3.

Data pada Tabel 4 menunjukkan bahwa distribusi frekuensi penilaian dosen mengenai kepraktisan Modikar Pekasi yang berada pada interval $X>3,25$ dengan kategori sangat mudah dilaksanakan adalah sebesar 25,00\%; sedangkan yang berada pada interval 2,5 $\leq X<3,25$ atau mudah dilaksanakan adalah sebesar $75,00 \%$. Sementara itu, tidak ada dosen yang menilai bahwa Modikar Pekasi sulit dilaksanakan dan sangat sulit dilaksanakan. Selanjutnya, ilustrasi mengenai kepraktisan Modikar Pekasi menurut penilaian dosen disajikan dalam bentuk diagram batang Gambar 2 .

Tabel 3. Distribusi Tingkat Kepraktisan Modikar Pekasi

\begin{tabular}{|c|c|c|c|c|}
\hline \multirow[b]{2}{*}{ No } & \multirow[b]{2}{*}{ Kepraktisan } & \multirow[b]{2}{*}{$\begin{array}{c}\text { Inter } \\
\text { val }\end{array}$} & \multicolumn{2}{|c|}{ Frekuensi } \\
\hline & & & $\begin{array}{c}\text { Frekue } \\
\text { nsi }\end{array}$ & $\begin{array}{c}\text { Perse } \\
\mathbf{n} \\
(\%)\end{array}$ \\
\hline 1 & $\begin{array}{l}\text { Sangat Mudah } \\
\text { Dilaksanakan }\end{array}$ & $\begin{array}{l}X> \\
3,25\end{array}$ & 2 & 25,00 \\
\hline 2 & $\begin{array}{c}\text { Mudah } \\
\text { Dilaksanakan }\end{array}$ & $\begin{array}{c}2,5 \leq \\
X< \\
3,25\end{array}$ & 6 & 75,00 \\
\hline 3 & $\begin{array}{c}\text { Sulit } \\
\text { Dilaksanakan }\end{array}$ & $\begin{array}{c}1,75 \\
\leq X< \\
2,5\end{array}$ & 0 & 0,00 \\
\hline 4 & $\begin{array}{c}\text { Sangat Sulit } \\
\text { Dilaksanakan }\end{array}$ & $\begin{array}{l}X< \\
1,75\end{array}$ & 0 & 0,00 \\
\hline & & Jumlah & 8 & $\begin{array}{c}100,0 \\
0\end{array}$ \\
\hline
\end{tabular}

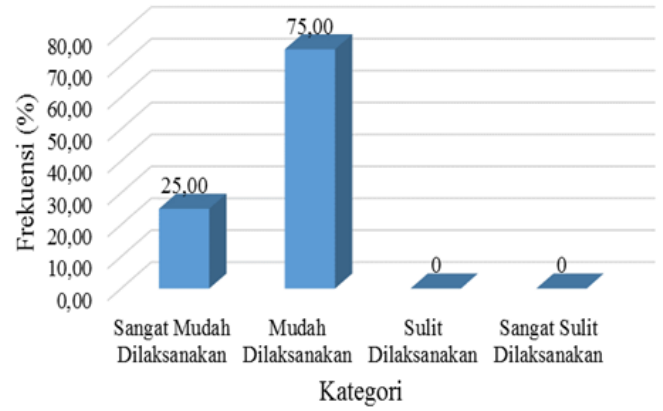

Gambar 2. Distribusi Kepraktisan Modikar Pekasi

\section{Efektivitas Modikar Pekasi}

Data penilaian dosen mengenai efektivitas Modikar Pekasi untuk diintegrasikan ke dalam pembelajaran mata kuliah praktik kerja, dikumpulkan dengan menggunakan instrumen angket bentuk tertutup, yang terdiri atas 1 pertanyaan. Secara keseluruhan, penilaian dosen mengenai tingkat efektivitas Modikar Pekasi untuk diintegrasikan ke dalam pembelajaran mata kuliah praktik kerja (sebelum pandemi Covid-19) menunjukkan nilai rata-rata sebesar 2,88. Hal ini dapat dimaknai bahwa penilaian dosen mengenai tingkat efektivitas 
Modikar Pekasi untuk diintegrasikan ke dalam mata kuliah praktik kerja pada kondisi sebelum pandemi Covid-19 berada pada interval 2,5 $\leq \mathrm{X}<3,25$ atau dengan kategori efektif.

Selanjutnya, data penilaian dosen mengenai keefektifan Modikar Pekasi untuk diintegrasikan ke dalam pembelajaran mata kuliah praktik kerja terkait kategori tingkat kepraktisan diilustrasikan pada Tabel 4 berikut.

Tabel 4. Distribusi Tingkat Efektivitas Modikar Pekasi

\begin{tabular}{|c|c|c|c|c|}
\hline \multirow[b]{2}{*}{ No } & \multirow[b]{2}{*}{ Kategori } & \multirow[b]{2}{*}{ Interval } & \multicolumn{2}{|c|}{ Frekuensi } \\
\hline & & & Frekuensi & $\begin{array}{c}\text { Persen } \\
(\%)\end{array}$ \\
\hline 1 & $\begin{array}{l}\text { Sangat } \\
\text { Efektif }\end{array}$ & $X>3,25$ & 1 & 12,50 \\
\hline 2 & Efektif & $\begin{array}{c}2,5 \leq X< \\
3,25\end{array}$ & 6 & 75,00 \\
\hline 3 & $\begin{array}{l}\text { Kurang } \\
\text { Efektif }\end{array}$ & $\begin{array}{c}1,75 \leq X \\
<2,5\end{array}$ & 0 & 0,00 \\
\hline 4 & $\begin{array}{c}\text { Tidak } \\
\text { Efektif }\end{array}$ & $X<1,75$ & 1 & 12,50 \\
\hline & & Jumlah & 8 & 100,00 \\
\hline
\end{tabular}

Selanjutnya, ilustrasi mengenai keefektifan Modikar Pekasi menurut penilaian dosen disajikan dalam bentuk diagram batang pada Gambar 3 .

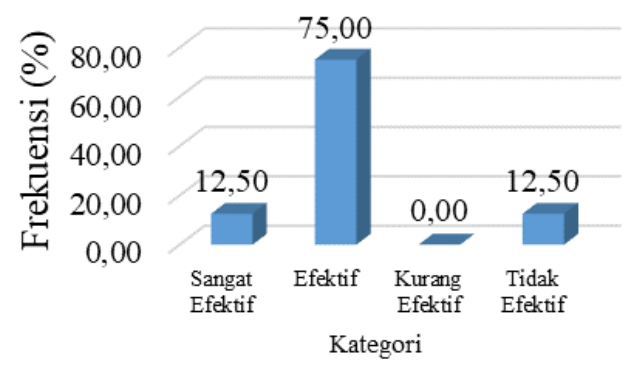

Gambar 3. Distribusi Tingkat Efektivitas Modikar Pekasi

Dengan melihat distribusi efektivitas Modikar Pekasi pada pembelajaran praktik kerja, dapat diketahui bahwa terdapat 1 responden yang menyatakan bahwa model tidak efektif untuk dilaksanakan. Untuk itu, diperlukan analisa lebih lanjut terhadap responden berdasarkan blok jurusan, sebagaimana disajikan pada Tabel 5 berikut.

Tabel 5. Efektivitas Modikar Pekasi untuk Setiap Blok Jurusan

\begin{tabular}{ccccc}
\hline $\begin{array}{c}\text { Blok } \\
\text { Jurusan }\end{array}$ & Mean & Min & Max & Std. \\
\hline PTBB & 3,00 & 3,00 & 3,00 & 0,00 \\
\hline PTSP & 3,50 & 3,00 & 4,00 & 0,70 \\
\hline PTMO & 3,00 & 3,00 & 3,00 & 0,00 \\
\hline PTEE & 2,00 & 1,00 & 3,00 & 1,42
\end{tabular}

Data hasil penelitian mengenai tingkat pemahaman dosen terhadap model Modikar Pekasi menunjukkan nilai rata-rata sebesar 3,32 pada skala 1- 4, atau dengan kategori sangat baik. Hal ini menunjukkan bahwa dosen dapat memahami dengan baik mengenai Modikar Pekasi, yang merupakan integrasi model pendidikan karakter pada pembelajaran praktik kerja, yang mencakup tahapan PDCA, Plan (P), Do (D) atau pelaksanaan pembelajaran, tahap Check (C) atau evaluasi pembelajaran, dan tahap Act (A) atau tindak lanjut hasil pembelajaran (Dudin et al., 2017).

Sementara itu, hasil penelitian juga menunjukkan bahwa penilaian dosen mengenai kepraktisan Modikar Pekasi yang merupakan model integrasi pendidikan karakter ke dalam mata kuliah praktik kerja juga menunjukkan bahwa Modikar Pekasi tersebut adalah praktis atau mudah diimplementasikan. Melihat tingkat pemahaman dosen yang baik, dan penilaian dosen bahwa model tersebut mudah dilaksanakan, maka sangat diharapkan bahwa Modikar Pekasi tersebut menjadi sangat mungkin untuk digunakan sebagai model integrasi pendidikan karakter ke dalam mata kuliah praktik kerja di FT UNY. Dengan demikian, Modikar Pekasi yang 
diadaptasikan dari teori Deming, dapat diimplementasikan serta berkembang secara berkelanjutan di FT UNY.

Pemahaman yang baik dari semua dosen mengenai integrasi pendidikan karakter ke dalam pembelajaran mata kuliah praktik kerja di FT UNY merupakan keniscayaan, karena pada dasarnya semua dosen telah lama melaksanakan pembelajaran mata kuliah praktik kerja dengan mengintegrasikan nilai-nilai karakter di dalamnya. Pembelajaran mata kuliah praktik kerja di FT UNY selain melatihkan keterampilan profesional, juga selalu melibatkan nilai-nilai sebagai sikap profesional, baik sebagai calon guru kejuruan maupun ahli teknologi. Termasuk dalam penilaian pembelajaran praktik kerja juga selalu menekankan pada sikap profesional, seperti: kedisiplinan, ketelitian, kerja keras, keselamatan kerja, kerjasama, tanggung jawab, dan sikap profesional lainnya sesuai karakteristik keterampilan yang dipelajari.

Dalam proses pembelajaran pendidikan tinggi, mahasiswa sebagai peserta didik harus dipacu untuk terus meningkatkan kapasitasnya secara mandiri. Peran dosen/pendidik dalam proses pembelajaran di perguruan tinggi adalah sebagai fasilitator, motivator dan evaluator bagi para mahasiswa. Hal ini dikarenakan mahasiswa dianggap telah mampu untuk melakukan eksplorasi terhadap ilmu pengetahuan yang diminatinya secara mandiri dan sesuai dengan apa yang dibutuhkan oleh masing-masing mahasiswa terhadap ilmu yang akan digunakan pada dunia kerja nanti. Selain itu, lembaga pendidikan tinggi juga harus mampu menciptakan iklim kampus yang menjaga dan menumbuhkan nilai-nilai karakter baik ke dalam kepribadian mahasiswa maupun masyarakat kampus lainnya sesuai dengan budaya dan karakter bangsa.

Hal ini selaras dengan pendapat yang dikemukakan oleh Hasanah (2013) bahwa seorang individu harus memiliki dua nilai pribadi dan sosial yang penting. Nilai-nilai tersebut sejatinya dapat mendukung proses berkembangnya potensi diri dalam segala bidang ilmu yang diminati. Karena selain membutuhkan tenaga kerja yang cakap dalam bidang pengetahuan dan keterampilan, dunia industri juga membutuhkan tenaga kerja yang peduli terhadap nilai-nilai kemanusiaan, memiliki kepribadian yang baik, dan akhlak yang mulia. Industri memandang bahwa aspekaspek kejujuran, etos kerja, tanggungjawab, disiplin, menerapkan prinsip-prinsip keselamatan dan kesehatan kerja, inisiatif, dan kreatifitas menjadi sangat penting, yang sekaligus menjadi kelemahan utama lulusan perguruan tinggi pada umumnya (Wagiran, 2010).

Selanjutnya, berdasarkan hasil penelitian juga diketahui bahwa efektifitas Modikar Pekasi untuk diintegrasikan ke dalam proses pembelajaran mata kuliah praktik kerja berada pada kategori efektif, dengan nilai sebesar 2,88 pada skala $1-4$. Meskipun demikian, terdapat satu respoden yang menganggap bahwa Modikar Pekasi tidak efektif untuk digunakan pada proses pembelajaran mata kuliah praktik kerja. Setelah dilakukan konfirmasi responden menyatakan bahwa Modikar Pekasi tersebut tidak efektif untuk diterapkan pada pembelajaran praktik di masa pandemi Covid-19 seperti saat ini. Hal ini menunjukkan bahwa responden kurang cermat dalam membaca petunjuk pengisian kuesioner yang diberikan, karena peneliti berkeinginan agar dosen memberikan penilaian keefektifan Modikar Pekasi untuk 
diterapkan dalam pembelajaran praktik kerja, dalam kondisi yang normal (bukan di masa pandemi Covid-19 seperti saat ini).

Implementasi pendidikan karakter secara terintegrasi ke dalam pembelajaran perlu didukung berbagai kegiatan pendukung agar dapat berjalan efektif. Hal ini adalah sesuai dengan prinsip efektivitas dalam mewujudkan pendidikan karakter sebagaimana digariskan oleh Kemendiknas (2010) yang merupakan aplikasi dari CEP's Eleven Principles of Effective Character Education By Thomas Lickona, yaitu: (1) mempromosikan nilai dasar etika selaku basis dan inti karakter; (2) mengidentifikasi karakter secara menyeluruh mencakup perasaan, perilaku dan pemikiran; (3) menggunakan metode yang proaktif, mendalam dan efektif dalam membangun karakter; (4) menciptakan komunitas sekolah yang memiliki rasa peduli; (5) memberikan kesempatan kepada peserta didik untuk mengimplementasikan perilaku yang baik; (6) memiliki cakupan pada kurikulum yang bermakna dan menantang yang menghargai semua peserta didik, membangun karakter mereka, dan membantu mereka untuk sukses; (7) mengusahakan tumbuhnya motivasi diri pada pada peserta didik; (8) memfungsikan seluruh staf sekolah sebagai komunitas moral yang berbagi tanggungjawab untuk pendidikan karakter dan setia pada nilai dasar yang sama; (9) terwujudnya pembagian kepemimpinan moral dan dukungan luas dalam membangun inisiatif pendidikan karakter; (10) memfungsikan keluarga dan anggota masyarakat sebagai mitra dalam usaha membangun karakter; dan (11) mengevaluasi karakter sekolah, fungsi staf sekolah sebagai guru-guru karakter, dan manifestasi karakter positif dalam kehidupan peserta didik.
Dengan memperhatikan prinsipprinsip tersebut, implementasi pendidikan karakter ke dalam pembelajaran perlu menggunakan metode yang proaktif, mendalam serta efektif dalam mengintegrasikan pendidikan karakter dalam pembelajaran praktik di FT UNY. Namun demikian, adanya perbedaan pendekatan pembelajaran yang digunakan antar blok jurusan di FT UNY kemungkinan disebabkan oleh perbedaan karakteristik keterampilan yang dipelajari di dalam pembelajaran mata kuliah praktik kerja. Hal ini juga dapat menyebabkan adanya perbedaan kultur dalam bengkel setiap blok jurusan yang berbeda. Mata kuliah praktik kerja di blok jurusan Pendidikan Teknik Elektro, Elektronika dan Informatika cenderung banyak berinteraksi dengan alat dan komputer. Sedangkan pelaksanaan pembelajaran pada mata kuliah praktik kerja di blok jurusan lain cukup banyak menuntut terjadinya interaksi antar individu dengan individu lain. Sebagai contoh, praktik kerja batu dan beton di blok jurusan Pendidikan Teknik Sipil dan Perencanaan, proses pembelajaran selalu dilaksanakan secara berkelompok dengan proyek yang dikerjakan secara bersamaan. Dengan metode tersebut mahasiswa harus membiasakan melaksanakan pekerjaan dan bertanggung jawab secara tim, harus mengembangkan kemampuan bekerjasama, dan menciptakan perasaan saling peduli antar sesama anggota tim. Sedangkan proses pembelajaran praktik yang dilaksanakan secara individu dan banyak berinteraksi dengan alat atau mesin cenderung kurang memberikan kesempatan kepada peserta didik untuk dapat mengembangkan kemampuan kerjasama dalam tim, dan saling peduli antar sesama anggota tim. 
Sementara itu, Kurniasih dkk. (2017) menyatakan banyak pihak beranggapan bahwa implementasi kebijakan pendidikan karakter dalam sistem pendidikan di Indonesia masih menghadapi tantangan utama yaitu untuk meningkatkan hasil pembelajaran yang masih rendah. Pernyataan tersebut sering dimaknai bahwa kebijakan pendidikan karakter dan kebijakan peningkatan mutu hasil belajar seakan-akan merupakan dua kebijakan yang saling bertolak belakang. Sehingga kebijakan pendidikan karakter dianggap sebagai pilihan yang sulit, karena kita tidak boleh mengabaikan upaya peningkatan mutu pendidikan kita yang juga masih rendah.

Seharusnya upaya peningkatan mutu hasil pendidikan dan pengembangan karakter peserta didik merupakan dua kebijakan yang dapat berjalan beriringan. Menurut Lickona (2012), pendidikan karakter dapat diartikan sebagai upaya untuk membentuk kepribadian seseorang melalui pendidikan yang hasilnya terlihat pada tindakan nyata dari seseorang tersebut dalam bentuk tingkah laku yang baik, jujur, bertanggung jawab, menghormati orang hak lain, kerja keras dan sebagainya. Pendidikan karakter mencerminkan keterkaitan antara pengetahuan, nilai, dan keterampilan untuk sukses di dalam kehidupan. Selain itu, pendidikan karakter juga akan bermanfaat bagi siswa untuk membentuk karakter dan budaya belajar dan berkarir yang dibutuhkan dalam pembelajaran dan untuk sukses di sekolah dan pekerjaan (Davidson et al., 2011). Jadi, pendidikan karakter bermanfaat dalam membentuk karakter siswa untuk menjadi orang yang baik di sekolah, pekerjaan, dan masyarakat (Almerico, 2014).

Davidson, Lickona \& Khmelkov (2008) mengidentifikasi empat peran penting karakter dalam kehidupan akademis, yaitu: (1) mahasiswa membutuhkan karakter kinerja (etos kerja, disiplin diri, ketekunan, inisiatif, kerja tim, dll.) untuk melakukan pekerjaan akademis yang terbaik; (2) karakter kinerja seperti kemampuan untuk bekerja keras, memecahkan permasalahan, menemukan kegembiraan dalam pekerjaan, dll. Dapat dikembangkan melalui pemberian tugas di sekolah; (3) mahasiswa membutuhkan karakter moral (rasa hormat, keadilan, kebaikan, kejujuran, dll.) untuk menciptakan hubungan kelas yang membuat lingkungan belajar yang kondusif; dan (4) mahasiswa juga dapat mengembangkan karakter moral dari tugas sekolah mereka (misalnya, dengan membantu teman-teman mereka untuk melakukan pekerjaan terbaik mereka melalui "budaya kritik "yang menawarkan umpan balik yang membangun, dengan mempelajari masalah etika dalam kurikulum, dan dengan menggunakan pembelajaran kurikuler mereka dalam proyek layanan yang membantu menyelesaikan masalah nyata di masyarakat).

\section{SIMPULAN}

Berdasarkan pada hasil penelitian dan pembahasan di atas, maka dapat dirumuskan kesimpulan sebagai berikut: (1) tingkat pemahaman dosen terhadap Model Pendidikan Karakter Pembelajaran Vokasi (Modikar Pekasi) secara keseluruhan memiliki nilai rata-rata sebesar 3,33 dari skala $1-4$, sehingga dapat disimpulkan bahwa dosen memiliki pemahaman yang baik terhadap model tersebut untuk diterapkan dalam pembelajaran mata kuliah praktik kerja; (2) penilaian dosen mengenai tingkat kepraktisan Modikar Pekasi untuk diterapkan dalam pembelajaran mata kuliah 
praktik kerja secara keseluruhan memiliki nilai rata-rata sebesar 3,00 dari skala $1-4$, ehingga dapat disimpulkan pula bahwa model ini mudah diterapkan dalam pembelajaran mata kuliah praktik kerja; dan (3) tingkat efektivitas Modikar Pekasi untuk diterapkan dalam pembelajaran mata kuliah praktik kerja secara keseluruhan memiliki nilai rata-rata sebesar 2,89 dari skala $1-4$, sehingga dapat ditarik kesimpulan bahwa model ini efektif untuk digunakan dalam pembelajaran mata kuliah praktik kerja dalam kondisi normal (bukan kondisi pandemi Covid-19) seperti saat ini.

\section{DAFTAR RUJUKAN}

Almerico, G. M. (2014). Building Character through Literacy with Children's Literature. Research in Higher Education Journal, 26(1), pp. 1-13. Retrieved from http://www.aabri.com/manuscripts/1 41989.pdf.

Davidson, M., Lickona, T., \& Khmelkov, V. (2008). Smart and good schools: A new paradigm for high school character education. In L. P. Nucci \& D. Narvaez (Eds.), Handbook of moral and character education (pp. 370-390). London, England: Routledge.

Davidson, M. et al. (2011). Values education: The Power Achieve Approach for Building Sustainability and Enduring Impact. International Journal of Educational Research, 50(3), 190-197. Retrieved from https://www.researchgate.net/public ation/251599568.
Ditjen Dikti (2012). Undang-undang Nomor 12 Tahun 2012, tentang Pendidikan Tinggi. Retrieved from https://jdih.setkab.go.id/PUUdoc/17 624/UU0122012.

Dudin, M.N. et al. (2017). The Deming Cycle (PDCA) Concept as a Tool for the Transition to the Innovative Path of the Continuous Quality Improvement in Production Processes of the Agro-Industrial Sector. European Research Studies Journal Volume XX, Issue 2B, 2017, 283-293.

Hasanah. (2013). Implementasi nilai-nilai Karakter di Perguruan Tinggi. Jurnal pendidikan karakter, 3 (2), Juni 2013, 186-195.

Kemendiknas (2010). Disain Induk Pendidikan Karakter Kementerian Pendidikan Nasional. Jakarta: Direktorat Mandikdasmen.

Kurniasih et al. (2017). Character Education Policy and Its Implications for Learning in Indonesia's Education System. Research on Improving Systems of Education.

Lickona, T. (1992). Education For Character: How Our School Can Teach Respect and Responsibility. New York: Bantam Books.

Lickona, T. (2012). Character Development in The Family. Dlm. Ryan, K. \& Mclean, G.F. Character Development in Schools and Beyond. New York: Praeger. 
Mulyadin \& Jaedun, A. (2019). Maja Labo Dahu Slogan in Character Education. Jurnal Pendidikan Karakter, Tahun IX, Nomor 2, Oktober 2019, 204 215 .

Peraturan Pemerintah Nomor 17 Tahun 2010, tentang Pengelolaan dan Penyelenggaraan Pendidikan. Jakarta: Setkab RI.

Rosalin, H. (2016). Implementasi Pendidikan Karakter Di Sekolah Dasar Islam Terpadu Hidayatullah Yogyakarta. Retrieved from http://eprints.uny.ac.id/46143/1/SK RIPSI_ROSALIN\%20HELGA\%20 AMAZONA_11511241001.pdf.

Suparno, P. (2012). Peran Pendidikan dan penelitian terhadap Pembangunan karakter Bangsa. Disajikan pada seminar Nasional yang diselenggarakan oleh LPPM UNY, tanggal 11-12 Mei 2012

Sumardjo, S., Pratama, G. N. I. P., \& Vemantyasto, T. N. (2020). Efektivitas Modul Estimasi Biaya Konstruksi Jalan pada Mata Pelajaran Estimasi Biaya Konstruksi Di SMK N 1 Purworejo. Jurnal Pendidikan Teknik Sipil,2(2), 104116.

Sutarto dkk. (2019). Character education model for engineering and technology towards sustainability: Integrating lessons learned from UTHM Malaysia and UNY Indonesia. Laporan Penelitian. Yogyakarta: FT UNY.
Titania, T., \& Widodo, S. (2020). Pengembangan Media Pembelajaran Video Animasi untuk Mata Pelajaran Mekanika Teknik Kelas X Desain Pemodelan dan Informasi Bangunan di SMK N 2 Yogyakarta. Jurnal Pendidikan Teknik Sipil, 2(2), 89-94.

Wagiran (2010). Pengembangan Karakter Berbasis Kearifan Lokal Hamemayu Hayuning Bawana. Jurnal Pendidikan Karakter, Tahun II, Nomor 3, Oktober 2012, 1 - 18.

Zuchdi, D. (2010). Humanisasi Pendidikan Menemukan Kembali Pendidikan Yang Manusiawi. Jakarta: Bumi Aksara.

Zuchdi, D. (2012). Implementasi Pendidikan Karakter di Perguruan Tinggi. Makalah disajikan dalam Workshop Redesain Pendidikan Karakter UNY tanggal 5 September 2012. 